\title{
Studies on preparation of low fat, sugar free mango shrikhand
}

\author{
P.A. SHELKE, S.R. SHEGOKAR, R.R. SHELKE, P.A. KAHAATE AND S.D. CHAVAN
}

\begin{abstract}
In present investigation attempt was made to study on preparation of low fat, sugar free mango shrikhand. For this purpose artificial sweetener sucralose with alphanso mango pulp was incorporated in buffalo skim milk chakka.Five treatments were design as base mix of 70 per cent skim milk chakka 30 per cent alphanso mango pulp added with 40 per cent cane sugar $\left(\mathrm{T}_{1}\right), 3.0$ per cent $\left(\mathrm{T}_{2}\right), 6.0$ per cent $\left(\mathrm{T}_{3}\right)$, 9.0 per cent $\left(\mathrm{T}_{4}\right)$ and 12.0 per cent $\left(\mathrm{T}_{5}\right)$, respectively. It was found that, acceptability score of $\left(\mathrm{T}_{1}\right),\left(\mathrm{T}_{2}\right),\left(\mathrm{T}_{3}\right),\left(\mathrm{T}_{4}\right)$ and $\left(\mathrm{T}_{5}\right)$ treatments of mango shrikhand sample were obtained 91.96, 85.01, 95.09, 89.36 and 87.37, respectively. On an average fat, protein, acidity, total solids and moisture percentage of treatments $\left(\mathrm{T}_{1}\right),\left(\mathrm{T}_{2}\right),\left(\mathrm{T}_{3}\right),\left(\mathrm{T}_{4}\right)$ and $\left(\mathrm{T}_{5}\right)$ were $8.65,5.73,1.31,63.47$ and $36.53 ; 1.47,10.26,1.56,36.52$ and 63.48; 1.38, 9.99, $1.51,38.50$ and $61.50 ; 1.33,9.69,1.45,40.35$ and $59.65 ; 1.29,9.31,1.40,41.78$ and 58.22 per cent, respectively. The result of present study concluded that, skim milk chakka, mango pulp and artificial sweetener could successfully used for the preparation of low fat, sugar free mango shrikhand.
\end{abstract}

KEY WORDS : Low fat, Sugar free mango shrikhand, Skim milk chakka, Sucralose, Sensory evaluation, Chemical composition

How to CITE THIS PAPER : Shelke, P.A., Shegokar, S.R., Shelke, R.R., Kahaate, P.A. and Chavan, S.D. (2014). Studies on preparation of low fat, sugar free mango shrikhand. Res. J. Animal Hus. \& Dairy Sci., 5(2) : 122-125.

\section{MEMBERS OF RESEARCH FORUM}

Address for correspondence :

P.A. Shelke, Department of Animal Husbandry and Dairy Science, Post Graduate Institute, Dr. Panjabrao Deshmukh Krishi Vidyapeeth, AKOLA (M.S.) INDIA.

Associated Authors':

S.R. Shegokar, R.R. Shelke and S.D.Chavan, Department of Animal Husbandry and Dairy Science, Post Graduate Institute, Dr. Panjabrao Deshmukh Krishi Vidyapeeth, AKOLA (M.S.) INDIA.

P.A. Kahaate, College of Agriculture, Dr. Panjabrao Deshmukh Krishi Vidyapeeth, AKOLA (M.S.) INDIA. 